\title{
THE DIGITAL EPHEMER: HENRY III OF FRANCE IN VENICE (1574)
}

\author{
Caterina Balletti, Francesco Guerra, Chiara Meneghello, Giulia Romanato \\ Università Iuav di Venezia, 30135 Venezia - Italy \\ (balletti@iuav.it, guerra2@iuav.it, ch.meneghello@gmail.com, giulia.romanato.gr@gmail.com)
}

KEYWORDS: Cultural Heritage, Ephemeral architecture, Venice, Photogrammetry, 3D reconstruction, 3D modelling, Andrea Palladio, Jacopo Sansovino.

\begin{abstract}
:
Sometimes digital reconstruction interfaces with the ephemeral aspect of the Cultural Heritage. Photogrammetric survey, integrated with the most up-to-date visualization technologies, aims to the production of $3 \mathrm{D}$ models that can recreate and document the artifacts that were made to be short-lived.

The paper deals with the documentation of an historical event: the stay of Henry III of France in Venice in 1574. This happening has been studied as part of the journey from Poland to France, undertaken by the king through Austria and northern Italy. Many royal events were organized and among the architectural and sculptural works that were made for the occasion, two stand out: the ephemeral triumphal arch and loggia designed by Andrea Palladio for the grand entry of the King and the three hundred sugar sculptures cast from moulds obtained from Jacopo Sansovino's workshop.

Historical research, iconography and cartography, along with the photogrammetric survey of some artworks still visible today, allowed the three-dimensional reconstruction of the temporary structures and sugar sculptures created for this historical event and made to last only for the ten days of his stay.

The purpose of this research is to map the movements of the King and recreate the works of art that were created for him in various parts of Venice, according to a geographic and scientific approach, by framing them in space and time and employing the 3D models to project the observer into $16^{\text {th }}$ century Venice.

The integration of methods and techniques pertaining to geomatics and three-dimensional computer graphics allow us to animate and reconstruct images of no longer existing places and works of art which were made to be fleeting but scenic at the same time and arouse amazement between the leading personalities of those times.

The "digitalization of the ephemeral" aims to bring these artifacts back to memory, following a meticulous process based on the examination of the historical sources together with cartographic data and a scientific survey.
\end{abstract}

\section{INTRODUCTION}

The knowledge of great historical events and architectural works can nowadays be achieved through digital technologies, aiming to a wider and deeper involvement; we are not only talking about analysing written records or observing paintings and engravings that got to us, but about attempting to immerse ourselves into a specific era to undertake a historical journey.

The theme that was tackled within this research is the reconstruction of a great event, of which hardly any trace endures; a story destined to remain in the Venetian memory, but not in its material one.

As stated in Stanco et al. (2011) paintings, frescoes, antique photographic prints, incunabula, old books, handwritten documents, sculptures, ceramic fragments, and other ancient manufacts constitute the elements of an extremely valuable and immense historical patrimony. The digitalization of these treasures opens up the possibility of using image processing and analysis and computer graphics techniques to preserve this heritage for future generations and to augment it with accessory information or with new possibilities for its enjoyment and use [Scopigno et al., 2011)].

The study starts from the history of Henry III of France who decided to flee Poland via Italy in 1574, to ascend the throne of France. One of the main stops of this journey was Venice itself, which was magnificently decorated and organized in every little detail. The ten days of the king's stay in Venice were examined, focusing on two main elements: the architectures built at Lido for his triumphal entry which were designed by Palladio, and the three hundred sugar statues that were displayed during the royal breakfast in the Doge's Palace, made from moulds coming from Sansovino's workshop.

The theme was approached starting from the historical research and was then based on the transition from the two-dimensional representation of iconographic sources to the three-dimensional reconstruction, with the aid of photogrammetry and modelling, rendering and post-production software (Guidi et al., 2011, Einaudi et al. 2020, Condorelli et al. 2018, Balletti et al., 2020). There are no drawings by Palladio that depict the architectures built at Lido, nor sketches that portray the sugar statues made from Sansovino's moulds. The graphic documentation now available was created after the event, turning out to be more iconographic than technical, and thus presenting some inconsistencies. This forced us to put forward hypotheses and interpretations based on the autographed treatises of the artists involved, crossing different representations, historical testimonies and by analogy.

In a society in which visual communication now has a fundamental role in disseminating information, the 3D model appropriately adjusted through today's technological possibilities - can provide a message that is easily perceived and extremely incisive in communicating information about Cultural Heritage (Balletti et al, 2016).

The three-dimensional reconstruction illustrated below is mainly based on two ways of operating: the first concerns the arch and loggia built at Lido, the second the sugar sculptures.

Regarding the two architectures, after having carried out a study of the written testimonies and having observed the paintings and engravings of the time, the representations by Antonio Visentini were CAD drawn, firstly through a two-dimensional approach, to then move on to the three-dimensional space through the modelling software.

For the realization of the sugar statues, on the other hand, a photogrammetric survey of two bronzes contained in the niches of the Loggetta del Sansovino was carried out, with a subsequent refining on the modelling software. For the realization of these statues, control points, surveyed topographically in 1996 on the occasion of the photogrammetric 
survey of the entire Loggetta, were used for the orientation of photogrammetric models. Working in the same reference system, it was possible to compare the data of the old survey with the current ones. Furthermore, renderings were then made in order to obtain reconstructions that could reproduce, even in the materials, the works created for this event.

\section{HENRY III}

Henry III of Valois was elected King of Poland in 1573 and reigned until 1574 when, informed of the death of his brother Charles IX, he fled Poland through Italy, to ascend the throne of France (Margaret of Valois, 1641).

The greatest Venetian artists, who were brought together to welcome the King to Venice, made memorable the ten days that the sovereign spent in the city, from which stand out: July 18th, day of the King's triumphal entry at Lido; July 25th, when the royal breakfast took place at the Doge's Palace. As for the triumphal entry, Henry III was escorted from Murano to Lido, where he was welcomed by one hundred and fifty brigantines of the Arts, and where he crossed the triumphal arch and the loggia designed by Palladio. Then he set off again on the Bucintoro, arriving at $\mathrm{Ca}$ ' Foscari around midnight.

On July 25th, after the Mass at Frari, he took part in the banquet at the Doge's Palace which counted three thousand guests. At 5 $\mathrm{pm}$, after the ball organized by the Compagnia della Calza, breakfast began in the Scrutinio Room, where three hundred sugar statues made from moulds of Sansovino's works were exhibited (Benedetti, 1574).

\section{THE TRIUMPHAL ARCH AND THE LOGGIA}

The positioning of the two architectures in front of the Church of San Nicolò, with the Forte of Sant'Andrea in the background, can be deduced from paintings and engravings (figure 1).

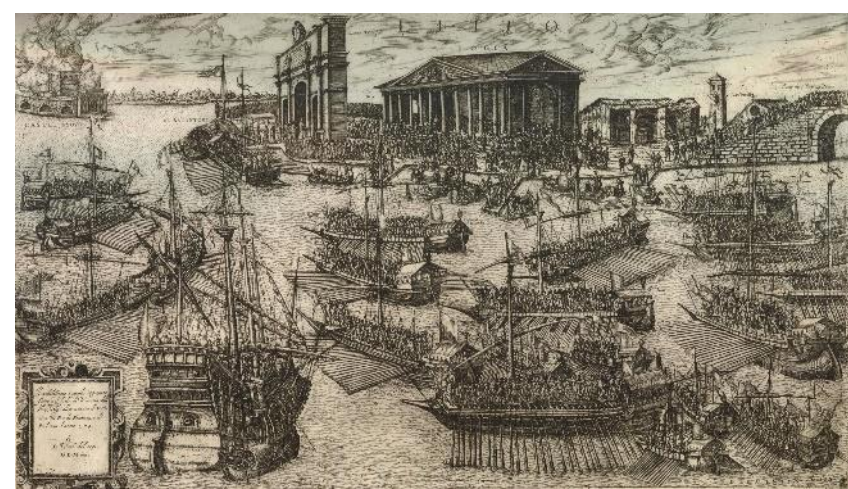

Figure 1. G.D.M. Master, The arrival of Henri III of France at the Lido in Venice in 1574, engraving, 1591, Venice, Biblioteca Nazionale Marciana.

Regarding the graphic sources depicting the arch and the loggia, two different collections of drawings by Antonio Visentini are available (figures $2 \mathrm{a}-2 \mathrm{~b}$ ) who drew them in 1756 by interpreting the historical sources. The similarity with the Arch of Septimius Severus from which Palladio took inspiration, can be seen especially from the eight columns and lesene (pilaster strips). For the two architectures, Palladio used the Corinthian order, recommended by Vitruvius to make buildings look more slender and graceful. A proportional analysis was carried out, based especially on the First of Palladio's The Four Books of Architecture, by comparing the modules with Visentini's drawings and the dimensions reported by Della Croce. The decorative apparatus of the two architectures, work of
Tintoretto, Veronese and Vassilacchi, was reconstructed by analogy from Visentini's drawings (figure 4), the only graphic sources that reproduced these elements, and from written evidences.

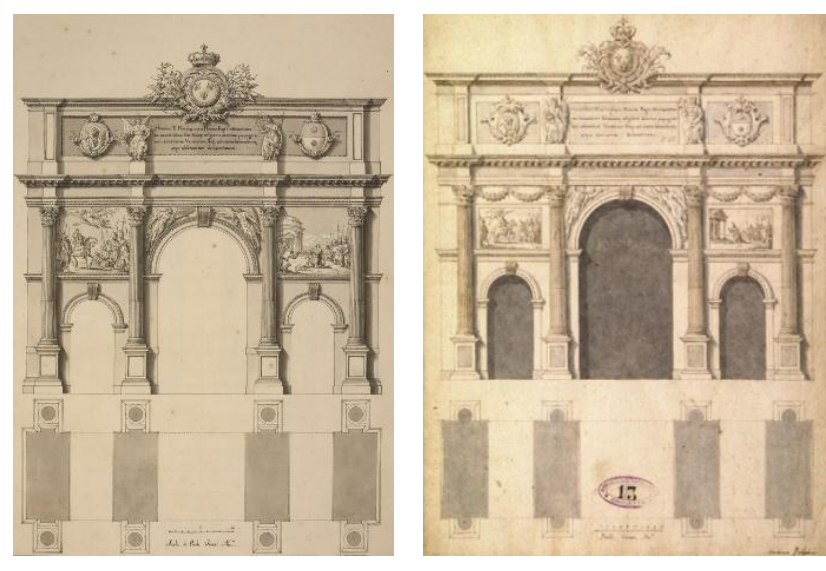

Figure 2a. A. Visentini, Restituzione ideale dell'arco trionfale per l'ingresso di Enrico III a Venezia, 1756, British Museum, London: elevation and plan.

Figure 2b. A. Visentini, Triumphal Arch built by Palladio (In Celebration of the Visit of Henry III of France to Venice, 1574), XVIII sec, Kansas, Nelson-Atkins Museum: elevation and plan.

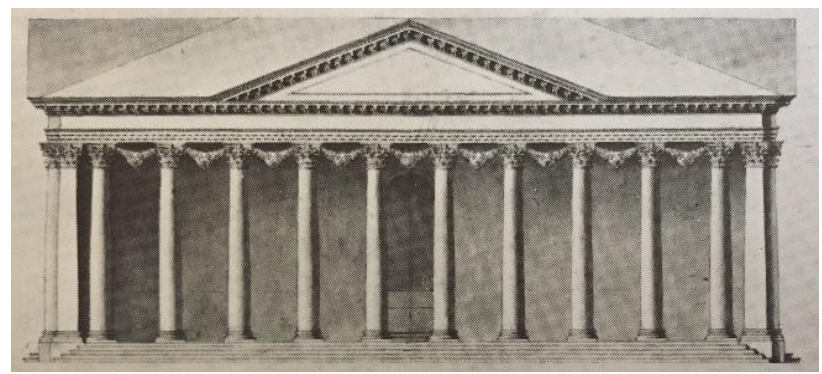

Figure 3. A. Visentini, Restituzione ideale della loggia per l'ingresso di Enrico III a Venezia, 1756, British Museum, Londra: facade.

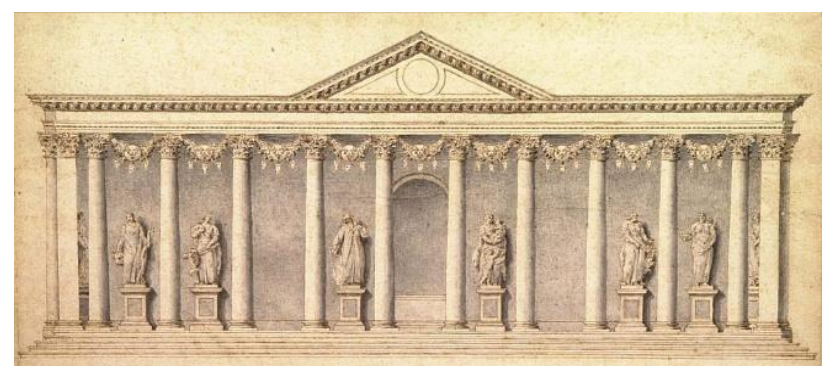

Figure 4. A. Visentini, Colonnade Built by Palladio (In Celebration of the Visit of Henry III of France to Venice, 1574), XVIII sec, Kansas, Nelson-Atkins Museum: facade.

\subsection{The Photogrammetric survey of A. Vicentino's painting}

Vicentino's painting (figure 5) represents one of the cornerstone images of this research: it is in fact the only coloured depiction of Henry III's arrival at Lido. Capturing the moment of the disembarkation, the artist shows the triumphal arch in the centre and the loggia in the background. It was decided to use this 
artwork as the context for the digital reconstruction, thus obtaining a new image.

A photogrammetric survey of a painting can be considered a special case of surveying a flat surface i.e. a relatively simple shape to model. For the presented works, the main purpose of the photogrammetric survey was to record the paintings' faithful photographic colour reproduction with a very high spatial resolution (Abate et al., 2014).

The painting, located in the Four Doors Room of the Doge's Palace, has considerable dimensions $(7.81 \times 3.67 \mathrm{~m})$, measured with the aid of the Leica Disto D8 laser distance meter.

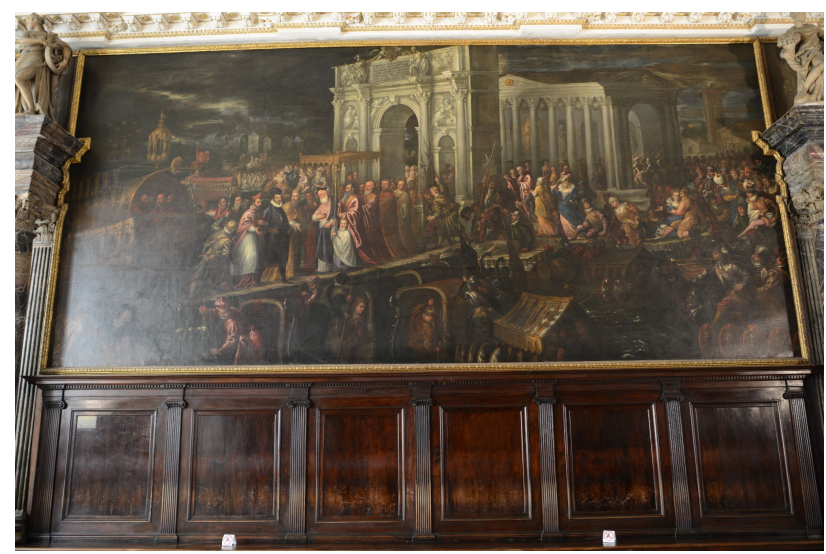

Figure 5. Andrea Vicentino, Enrico III re di Francia arriva a Venezia accolto dal doge Alvise Mocenigo e dal Patriarca, olio su tela, 7,81×3,67 m, 1595-1600, Venezia, Palazzo Ducale, Sala delle Quattro Porte.

The lighting to which the painting is subjected was studied in preparation for the survey: it is affected by indirect light coming from the large windows on both sides of the room, and by direct light generated by two lamps. The oil painting technique made the canvas very reflective, which is why there are overexposed areas in the images acquired by the camera, especially at the lower corners of the painting, preventing it from being viewed correctly.

We opted to use a polarizing filter in order to polarize a part of the light and reduce the light's intensity, saturate the colours and increase the contrasts.

The photogrammetric shots were taken with a Nikon D800 digital reflex camera with Nikon-Nikkor $50 \mathrm{~mm}$ lens, at $5.5 \mathrm{~m}$, with three different inclinations of the vertical axis of the camera, for a total of seventeen frames. The distance of the centre between one frame and the other is $\sim 0.50-0.60 \mathrm{~m}$, to obtain a covering of at least $60 \%$. Subsequently, three shots were taken to frame the painting in its entirety, again with the Nikon-Nikkor $50 \mathrm{~mm}$ lens, to ensure better alignment of the frames. Lastly, some shots were taken with a Nikon-Nikkor $28 \mathrm{~mm}$ lens in order to catch the entire canvas in a single frame, one with the camera in normal position, and two by tilting the horizontal axis of the camera towards the centre of the painting, for a better alignment of the frames and to avoid drift during the relative external orientation of the frames.

The frames were processed using the Agisoft Metashape software. After having scaled the model, masks were created on the images to exclude any element of disturb.

The real pixel size (GSD) was calculated equal to $0.5 \mathrm{~mm}$, so the pixel size for exporting the orthophoto (figure 6) is $0.5 \mathrm{~mm}$, for the 1: 5 scale.

The orthophoto has been elaborated with Adobe Photoshop, making a manual selection on the two architectures painted by Visentini and replacing them with the two models obtained from the $3 \mathrm{D}$ reconstruction (figure 8 ).

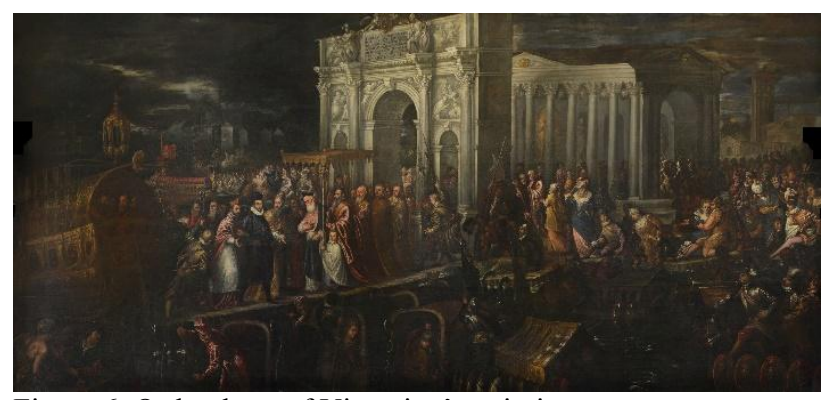

Figure 6. Orthophoto of Vicentino's painting.

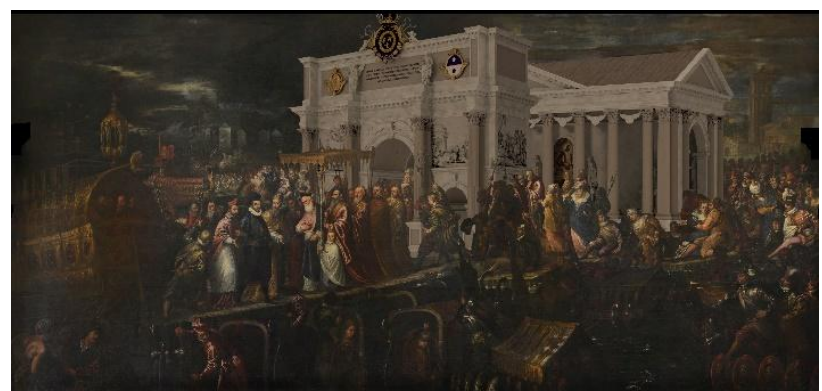

Figure 7. Photomontage of the 3D models inside the painting.

\subsection{The 3D reconstruction of the architectures built at Lido}

Visentini's drawings have been scaled using the graphic scale in venetian feet and, starting from the redrawing, the two architectures were modelled extruding the elements from the redesigned profiles, on Autodesk 3ds Max software (figure 8).

The arch's columns, on the other hand, were modelled separately to obtain the fluting and cabling of the shaft; furthermore, to create the coat of arms of Saint Mark, a photogrammetric survey of the lion of Saint Mark was carried out at Rialto (figures $9 a-9 b$ ).

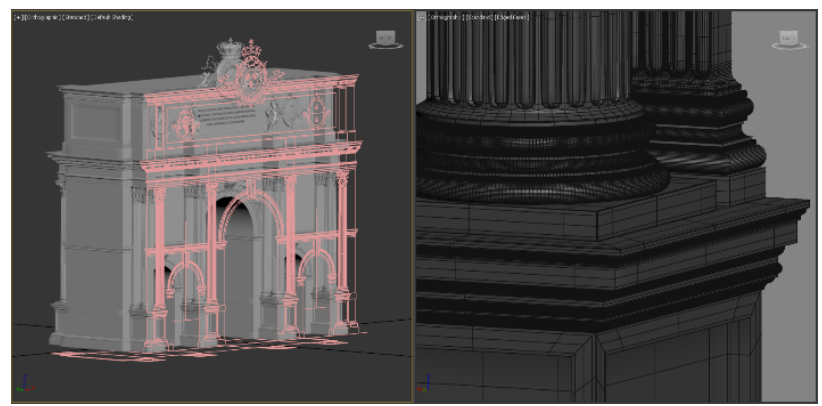

Figure 8. Making of the 3D model of the triumphal arch.
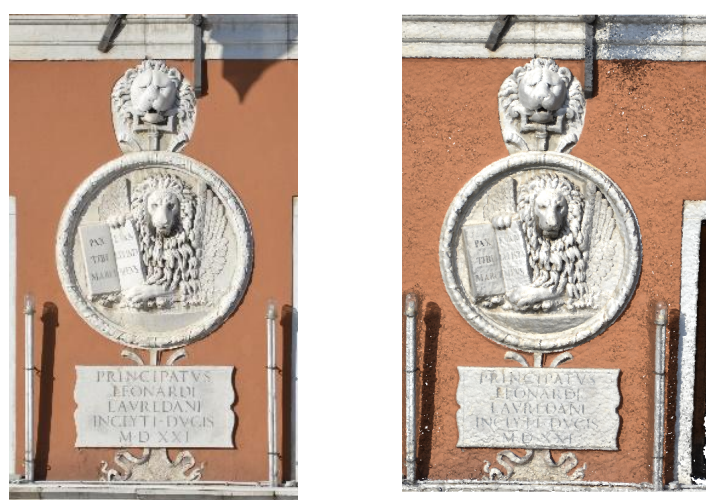

Figure 9a. Lion of Saint Mark in Rialto. Figure 9b. Dense cloud of the photogrammetric model of the lion of Saint Mark. 
The decorations of the trabeation and cornice were modelled starting from the representations found in the First of Palladio's The Four Books of Architecture, while the modelling work for the statues was carried out by analogy, as the graphic sources were not very detailed.

The two architectures, that were built in quickly perishable materials such as wood, papier-mâché, stucco and cloth and painted to imitate marble, are represented in colour only in Vicentino's painting, so textures that imitate the marble surface were applied for the photorealistic visualization of the models,

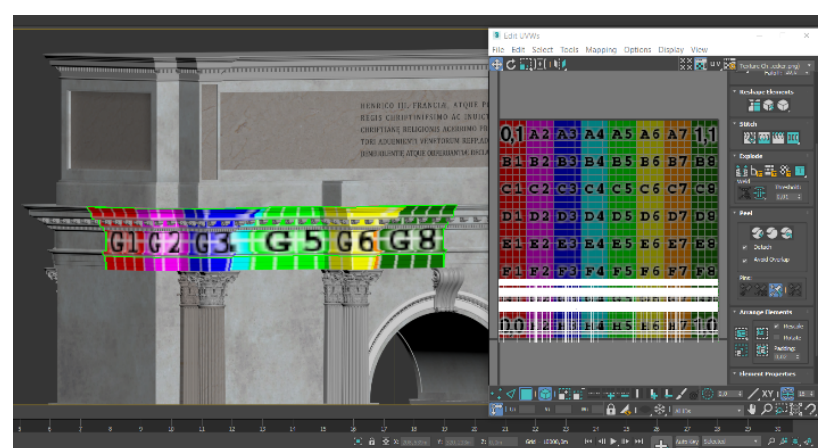

Figure 10. Texture mapping using the Unwrap UVW modifier

not varying much from the painting that depicted them (figure 10).

Lastly, the photorealistic renderings (figure 11) of the two architectures were created using the Corona Renderer render engine, while the animations of the two models were made using the V-Ray render engine, creating a hypothetical setting and setting the sunlight corresponding to the arrival time of Henry III at Lido.

\subsection{THE SUGAR SCULPTURES}

The second event that was examined in depth is the royal breakfast held on July 25th in the Scrutinio Room of the Doge's Palace, which presented three hundred sugar sculptures made by Nicolò della Cavalliera, from moulds coming from Sansovino's workshop (Kociszewska, 2020). It is reported by the written testimonies, especially Della Croce (1574), that two of the sugar statues depict Pallas and Mercury, and these can trace back to the two bronze statues of Pallas and Mercury located in the Loggetta del Sansovino on Saint Mark's Square. For this reason, a photogrammetric survey of the statues has been conducted.

\subsection{The photogrammetric survey of the Loggetta del Sansovino}

A survey of the Loggetta del Sansovino had already been carried out in 1996 by the IUAV photogrammetry lab: the photogrammetric shots were taken with a semi-metric single camera model Rollei 6006 and the topographic survey was carried out with the Nikon DTM A10LG total station.

It was decided to produce a photogrammetric model (figure 12) by scanning the positives of the shots using the Epson GTscanner $10000+$, at a resolution of $96 \mathrm{dpi}$, and subsequently orienting them on the monograph, generating the point cloud and the mesh on the Agisoft Metashape software.

However, the result did not allow to obtain detailed models of the statues of Pallas and Mercury.

For this reason, a new photogrammetric survey of the Loggetta del Sansovino was conducted with a digital reflex camera, model Nikon D800 with stabilized lenses of 28 and $85 \mathrm{~mm}$.
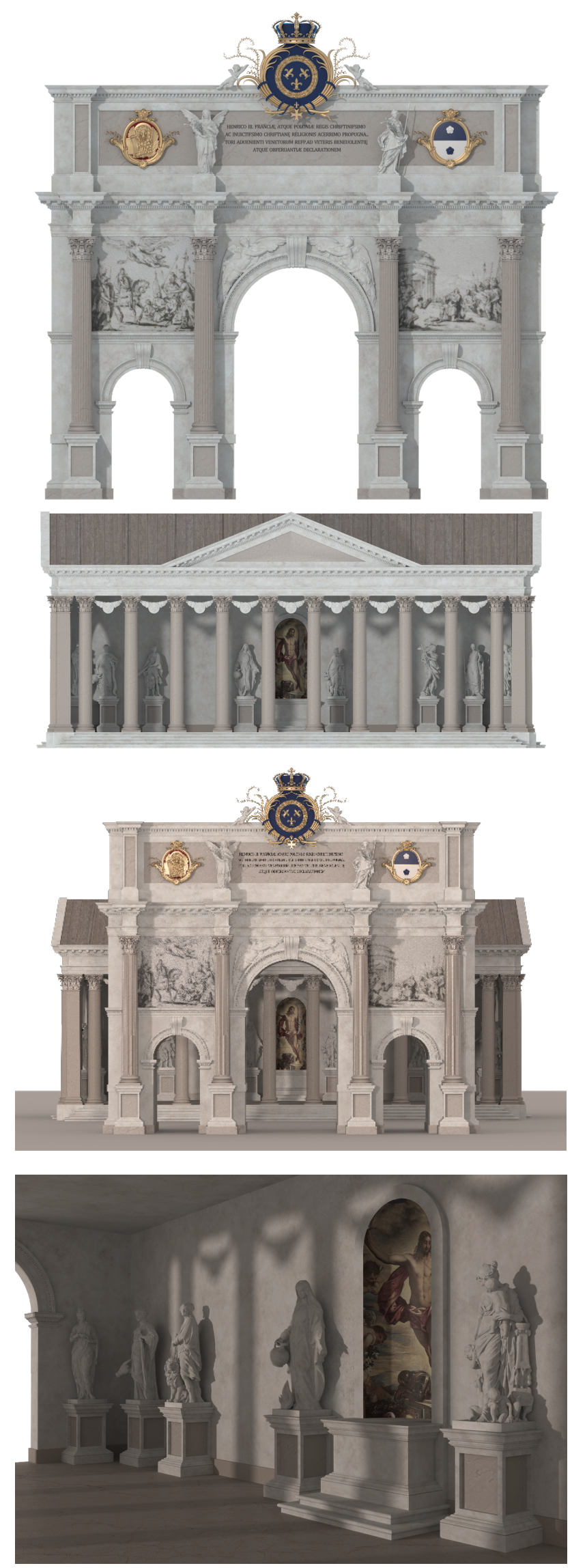

Figure 11. Photorealistic visualization of the 3D models. 
The shots were taken both inside and outside the terrace of the Loggetta, to then be oriented on the control points acquired from the 1996 topographic survey, with a residual error of \pm 8 $\mathrm{mm}$.

\subsection{Comparison of photogrammetric data 1996-2021}

The results obtained from the two surveys, oriented on the same reference system from 1996, have been compared by performing a cloud to mesh comparison and a mesh-to-mesh comparison on the software Cloud Compare. The mesh obtained from the photogrammetric survey of 2021 was maintained as reference for both comparisons because it was thought to be more suitable for the reconstructions, since the quality of the digitization of the positives of 1996 was not adequate.

In the cloud to mesh ( $\mathrm{C} 2 \mathrm{M})$ comparison, the real distance between the vertices of the surface and the points of the cloud is calculated using the comparison algorithm, while in the meshto-mesh (M2M) comparison the distance is calculated between the vertices of the two surfaces (figures 14-15).

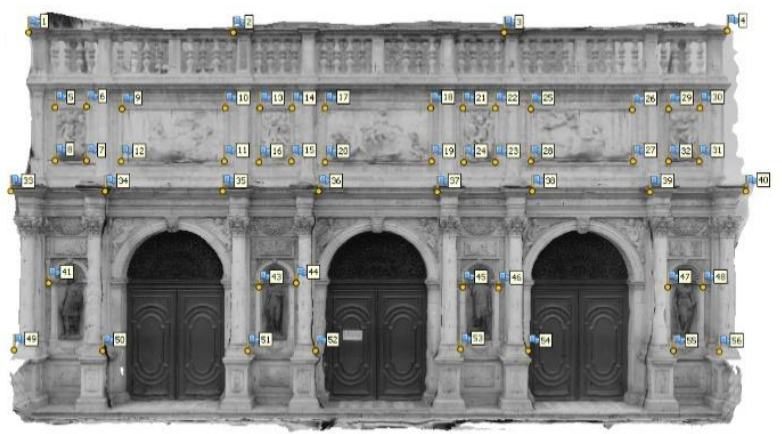

Figure 12. Mesh of the '96 photogrammetric model.

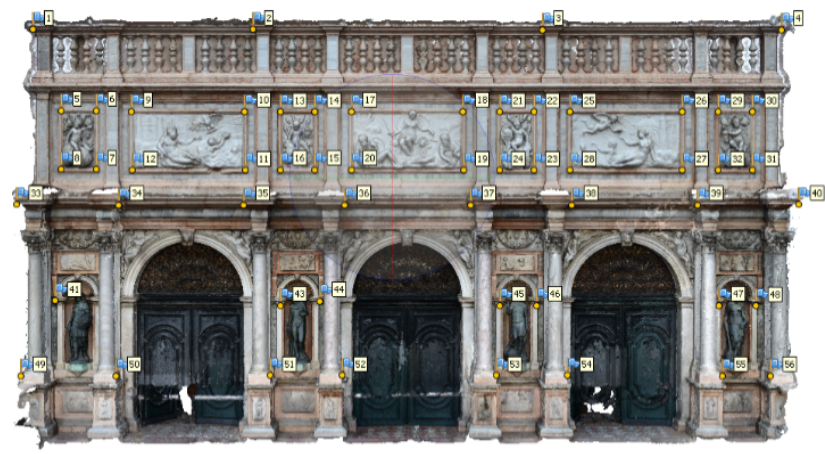

Figure 13. Mesh of the 2021 photogrammetric model

The comparison shows a resulting scalar field according to a range that varies from -0.5 to $0.5 \mathrm{~m}$, to exclude from the comparison all the points that do not belong to the surface of the facade (in this case the blue $>$ green $>$ yellow $>$ red scale was used).

The result of the scalar field adapted to a Gaussian (or normal) distribution was then observed, showing the scalar histogram and a curve corresponding to the adapted distribution.

The two values obtained do not differ much from each other, thus showing a standard deviation of around $\pm 3 \mathrm{~cm}$ of distance between the models of the two surveys (figures 16a-16b).

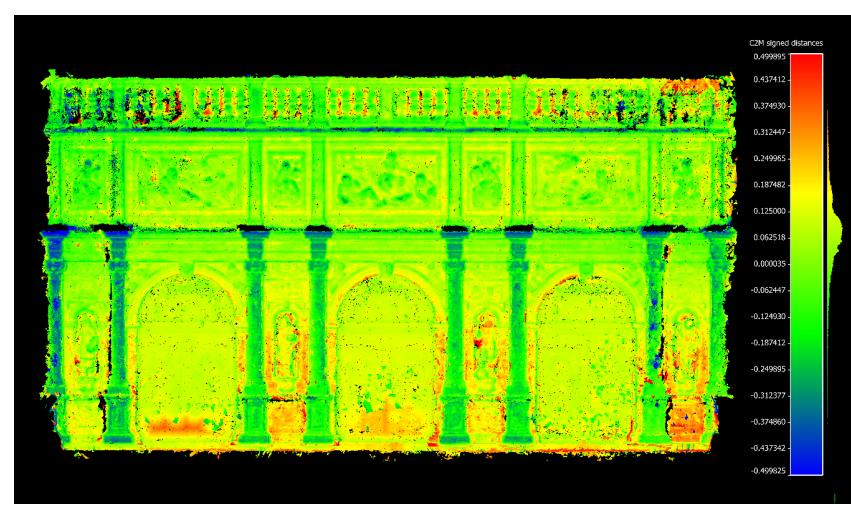

Figure 14. Comparison cloud to mesh (C2M).

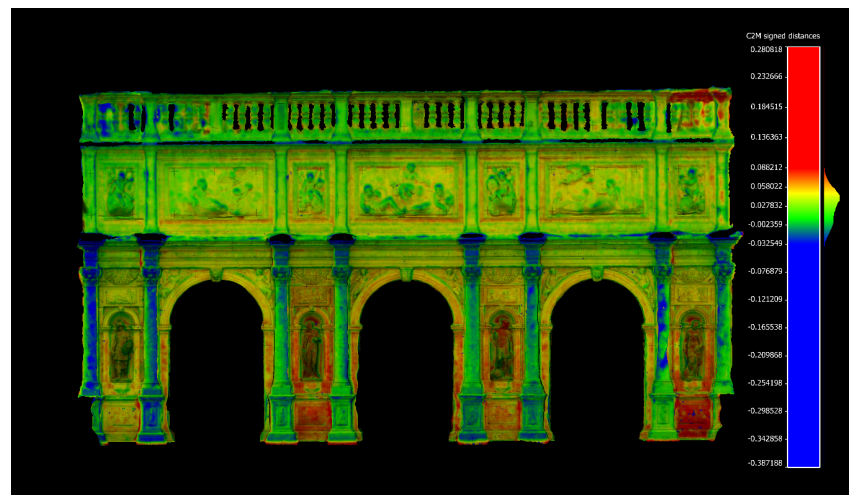

Figure 15. Comparison mesh to mesh (M2M).
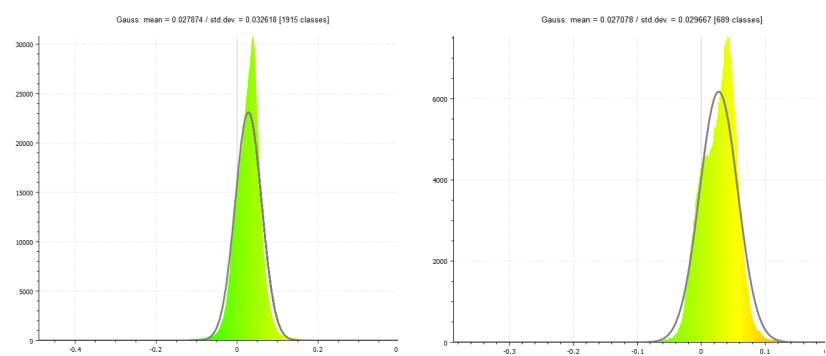

Figure 16a. C2M Scalar histogram cloud to mesh. Figure $16 \mathrm{~b}$. M2M Scalar histogram.

\subsection{The Photogrammetric survey of the bronze statues}

For the reconstruction of the statues of Pallas and Mercury, a detailed photogrammetric survey was carried out inside the terrace of the Loggetta. Two different cameras were used: a Nikon D800 model digital SLR with a focal length of $28 \mathrm{~mm}$ to obtain radial shots at different angles; a compact digital Sony RX100 model, with a much lower weight, mounted on a telescopic rod and controlled remotely, in order to reach a greater height and a normal position of the camera. The integration of the frames taken with the two cameras was then performed for each statue, in order to generate an exhaustive three-dimensional model.

To carry out the absolute external orientation of the models, the coordinates of six architectural points were obtained from the point cloud of the 2021 façade survey, as the monograph created with the topographic survey of 1996 did not provide a quantity of support points necessary for the georeferencing of the models of the two statues. 

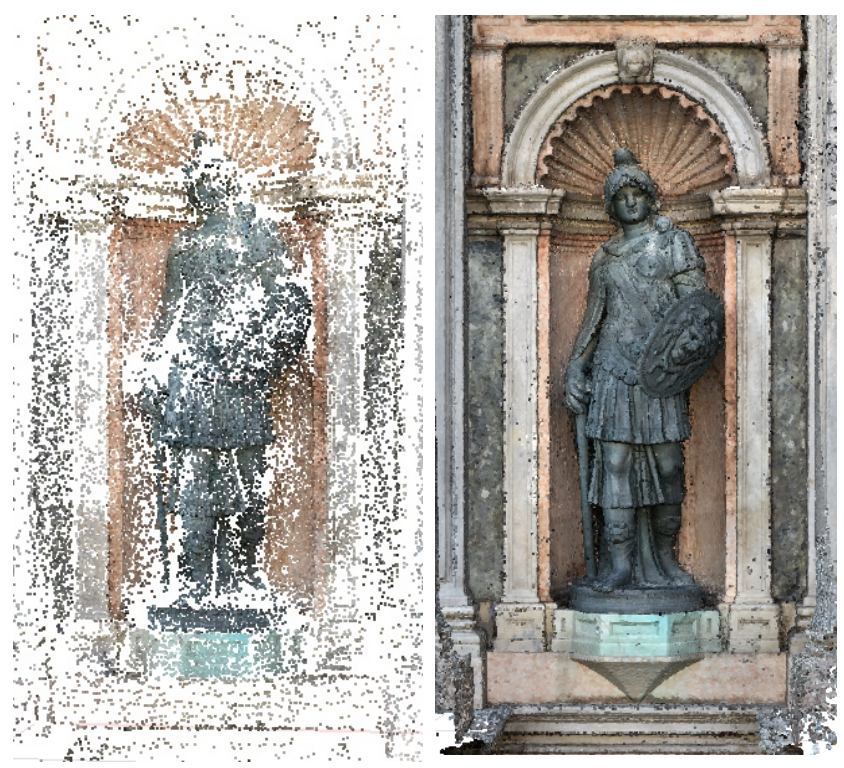

Figure 17. Tie points and dense cloud of the photogrammetric model of Pallas.

The mesh of both models (figure 18) was generated by enabling the interpolation algorithm, through which the software interpolates some surface areas within a certain radius around each point of the dense cloud, resulting in the automatic coverage of some holes of the surface (Agisoft Metashape 2019 Manual).

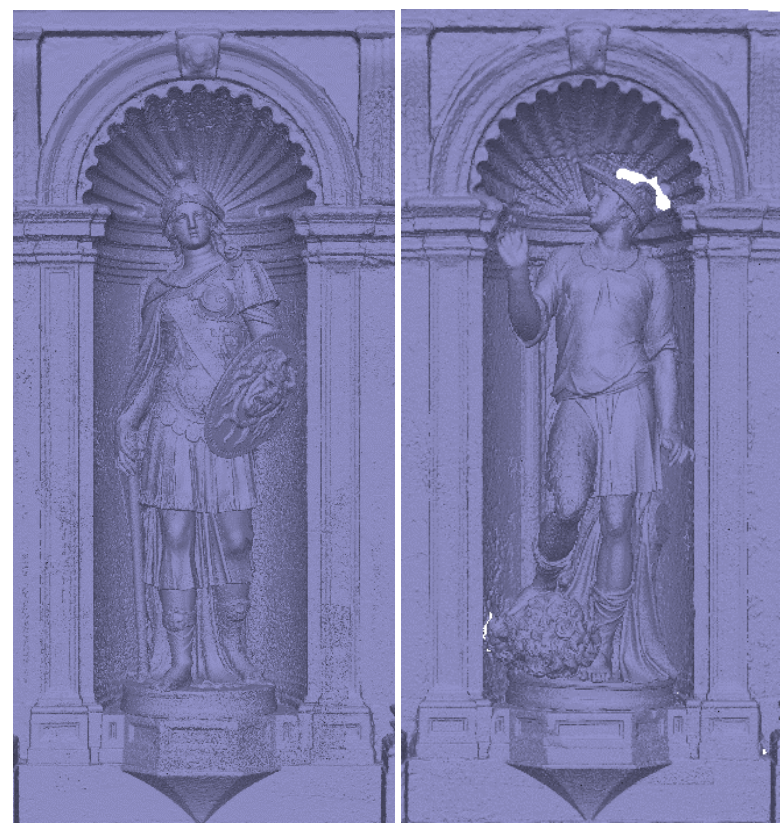

Figure 18. Mesh of the models of Pallas and Mercury.

\subsection{The 3D model of the statues}

At the end of the processing, the meshes of Pallas and Mercury presented missing parts and elements not consistent with the real form of Sansovino's sculptural work, due to the interpolation of the mesh generated on the Agistoft Metashape software. Both models also had a hole in the back due to the technique of realisation of the bronzes, that consists of leaving them empty inside and open on the back (Boucher, 1991)

The first phase of the refinement process was carried out on the Geomagic Wrap software, to eliminate the architectural parts that surrounded the models of the statues and to recreate the missing parts of the mesh. Since the latter is a polygonal surface obtained from the result of the triangulation of the points of the cloud from which it is generated, in case of lack of points the interpolation algorithm eliminates those too distant from each other, generating holes on the surface which must be closed manually to obtain a three-dimensional model geometrically correct.

After having generated the missing parts of the two models by creating new polygonal surfaces tangent to the already existing faces, the next intervention was operated on the surface itself, on the Blender software (figure 19-20). The excessive roughness of the surface has been eliminated using a smooth brush, intervening on the very sharp vertices while preserving the shapes and volume of the two meshes, so as not to excessively modify the result obtained from the photogrammetric survey. For the hole on the rear part, on the other hand, the drapery represented on the sculptures has been recreated.

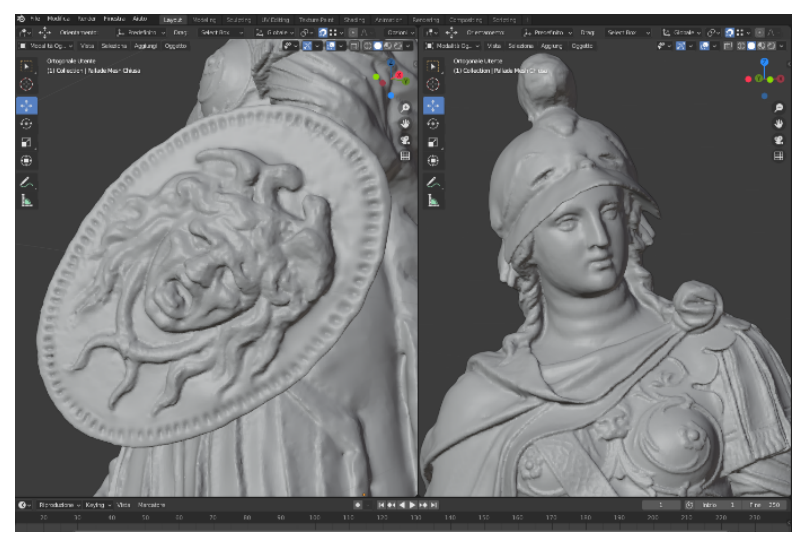

Figure 19. Mesh of Pallas in the Blender software.

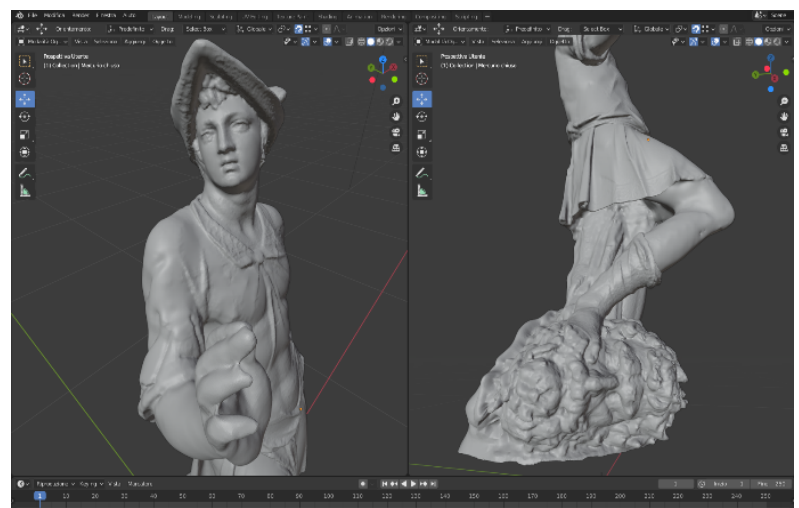

Figure 20. Mesh of Mercury in the Blender software.

For the photorealistic visualisation of the models, processing was performed on the Autodesk 3ds Max software; the meshes have been down-sampled, to reduce the computational load given to the render engine, Corona Renderer.

The texture that was applied to the models reproduces the crystalline surface of sugar, pink for anthropomorphic statues and white for the others, as reported by historical sources (Porcacchi, 1574; Dorron, 1574).

Subsequently, the models were placed inside the Scrutinio Room to recreate the atmosphere of the breakfast organized for the King. The results obtained from the reconstruction are shown below (figure 21-22). 


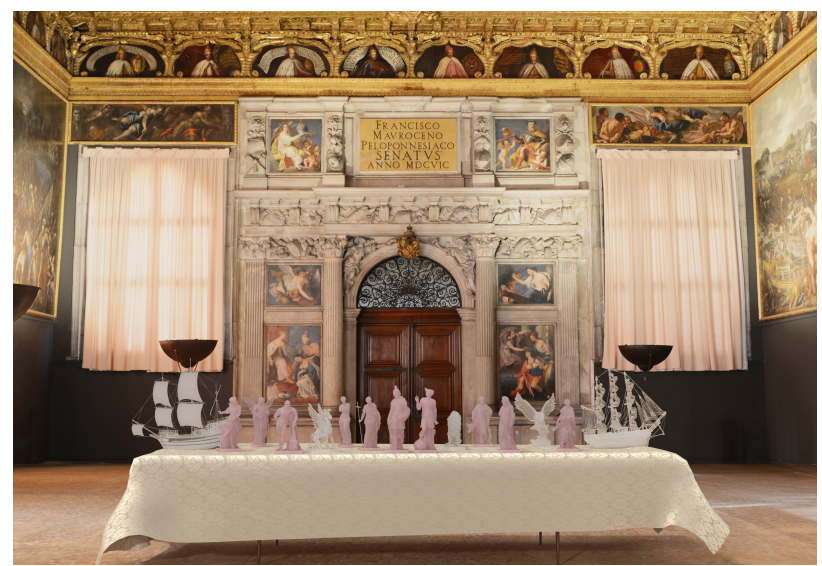

Figure 21. 3D visualization of the sugar sculptures in the Scrutinio Room.

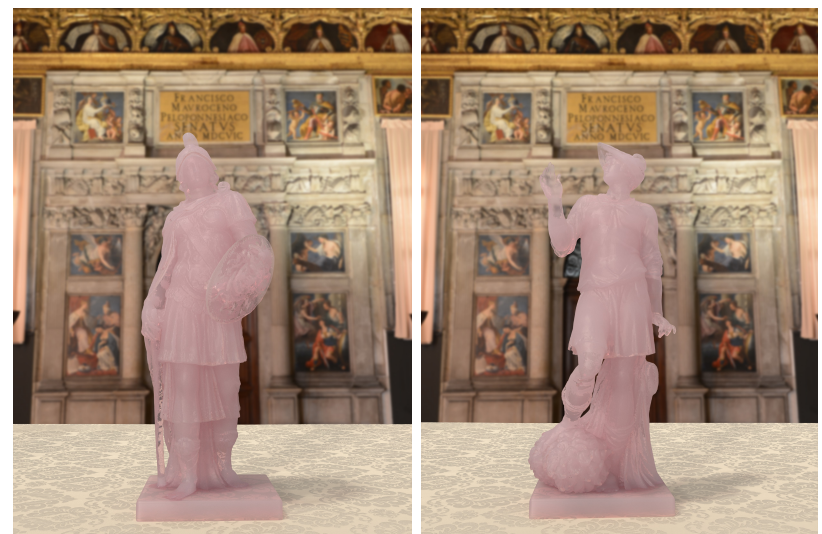

Figure 22. 3D visualization of the sugar sculptures of Pallas and Mercury.

\section{CONCLUSION AND FUTURE WORKS}

The study of Henry III's stay in Venice made it possible to undertake the digital reconstruction of a cultural heritage that no longer exists and that had been brought to light exclusively by written and graphic testimonies, until now. The goal was to "digitize the ephemeral", both for what concerns the architectures at Lido and the sugar statues, as well as for the movements of the King within the city and the events and parties organized in his honour.

A vertical focus was made on the two architectural works erected at Lido and on the sugar sculptures created for the royal breakfast at the Doge's Palace, but the same process could be extended to everything that is reported to have happened during the King's stay in the Venetian territory.

The use of a rigorous technique such as the photogrammetric survey has helped to faithfully reproduce the surfaces of the sculptural artifacts for the reconstruction of the sugar statues, and the redundancy of the acquired data has allowed not to have to intervene excessively for their re-elaboration on the modelling software, therefore not detaching from what was the starting point. The 3D models were subsequently contextualized, in order to create images that illustrate the information obtained from the analysis of the case study.

The production of these 3D models can later lead to the physical realization of these ephemeral architectures and statues, with the help of 3D printing. Numerous points remain to be analysed on the stay of Henry III in Venice and the procedure used for this case study can be applied to all the cities visited by the King during his journey to France; each stage was in fact organized in the smallest details with great pomp and magnificence to welcome the great guest, and the descriptions of these events were left in the form of written testimony for the centuries to come, generating material that lends itself well for this type of digital reconstruction.

\section{ACKNOWLEDGEMENTS}

The author would like to thank the Procuratoria di San Marco and Fondazione Musei Civici di Venezia for their availability.

\section{REFERENCES}

Stanco, F., Battiato, S., Gallo, G., 2011. Digital Imaging for Cultural Heritage Preservation. Taylor \& Francis Group.

Scopigno, R., Callieri, M., Cignoni, P., Corsini, M., Dellepiane, M., Ponchio, F., Ranzuglia, G., 2011. 3D Models for Cultural Heritage: Beyond Plain Visualization. Computer 44, 7 (July 2011), 48-55.

G. Guidi, M. Russo, 2011. Diachronic 3D reconstruction for lost cultural Heritage. Int. Arch. Photogramm. Remote Sens. Spatial Inf. Sci., XXXVIII-5/W16, (2011) 371-376

Einaudi, D., Spreafico, A., Chiabrando, F., and Della Coletta, C., 2020. FROM ARCHIVE DOCUMENTATION TO ONLINE 3D MODEL VISUALIZATION OF NO LONGER EXISTING STRUCTURES: THE TURIN 1911 PROJECT, Int. Arch. Photogramm. Remote Sens. Spatial Inf. Sci., XLIII-B22020, 837-844.

Condorelli, F., Rinaudo, F., 2018. Cultural heritage reconstruction from historical photographs and videos, Int. Arch. Photogramm. Remote Sens. Spatial Inf. Sci., XLII-2, 259-265.

Balletti, C., Dabrowski, M., Guerra, F., Vernier, P., 2020. Digital reconstruction of a lost heritage: The San Geminiano's church in San Marco's Square in Venice. 2020 IMEKO TC-4 International Conference on Metrology for Archaeology and Cultural Heritage, pp. 304-310.

C. Balletti, F. D'Agnano, F. Guerra, P. Vernier, 2016. From point cloud to digital fabrication: a tangible reconstruction of $\mathrm{Ca}$ ' Venier dei Leoni, the Guggenheim museum in Venice. $\mathrm{v}$ Int. Arch. Photogramm. Remote Sens. Spatial Inf. Sci., III-5, (2016).

Abate, D., Menna, F., Remondino, F., and Gattari, M. G.: 3D painting documentation: evaluation of conservation conditions with 3D imaging and ranging techniques, Int. Arch. Photogramm. Remote Sens. Spatial Inf. Sci., XL-5, 1-8,

Karl Kraus, 1998. Fotogrammetria. Teoria e applicazione. Levrotto \& Bella, 1998.

Margherita di Valois, 1641. Memorie della regina Margherita di Valois, moglie d'Henrico IV il grande, Venezia, Giuseppe Sarzina.

Tommaso Porcacchi, 1574. Le attioni d'Arrigo terzo Re di Francia et quarto di Polonia, descritte in dialogo, Giorgio Angelieri, Venezia.

Andrea Palladio, 1570. I quattro libri dell'architettura, Venezia. 
Pierre de Nolhac, Angelo Solerti, 1890. Il viaggio in Italia di Enrico III re di Francia e le feste a Venezia, Ferrara, Mantova e Torino, L. Roux, Torino.

Ewa Kociszewska, Displays of Sugar Sculpture and the Collection of Antiquities in Late Renaissance Venice, in «Renaissance Quarterly», 73, 2020, pp. 441-488.

Marsilio della Croce, L'historia della publica et famosa entrata in Vinegia del serenissimo Henrico III re di Francia, et Polonia, 1574.

Rocco Benedetti, Le feste et trionfi fatti dalla sereniss. signoria di Venetia nella felice venuta di Henrico III. christianiss. re di Francia, e di Polonia, Giordano Ziletti, Venezia, 1574. 